\title{
Soldering of Copper-Clad Niobium-Titanium Superconductor Composite
}
A. J. Moorhead
J. J. Woodhouse
D. S. Easton

\section{OAK RIDGE NATIONAL LABORATORY}




\section{DISCLAIMER}

This report was prepared as an account of work sponsored by an agency of the United States Government. Neither the United States Government nor any agency Thereof, nor any of their employees, makes any warranty, express or implied, or assumes any legal liability or responsibility for the accuracy, completeness, or usefulness of any information, apparatus, product, or process disclosed, or represents that its use would not infringe privately owned rights. Reference herein to any specific commercial product, process, or service by trade name, trademark, manufacturer, or otherwise does not necessarily constitute or imply its endorsement, recommendation, or favoring by the United States Government or any agency thereof. The views and opinions of authors expressed herein do not necessarily state or reflect those of the United States Government or any agency thereof. 


\section{DISCLAIMER}

Portions of this document may be illegible in electronic image products. Images are produced from the best available original document. 


\section{Printed in the United States of America. Available from National Technical Information Service \\ U.S. Department of Commerce 5285 Port Royal Road, Springfield, Virginia 22161}

Price: Printed Copy $\$ 4.00$; Microfiche $\$ 3.00$

This report was prepared as an account of work sponsored by the United States Government. Neither the United States nor the Energy Research and Development Administration/United States Nuclear Regulatory Commission, nor any of their employees, nor any of their contractors, subcontractors, or their employees, makes any warranty, express or implied, or assumes any legal liability or responsibility for the accuracy, completeness or usefulness of any information, apparatus, product or process disclosed, or represents that its use would not infringe privately owned rights. 
Contract No. W-7405-eng-26

METALS AND CERAMICS DIVISION

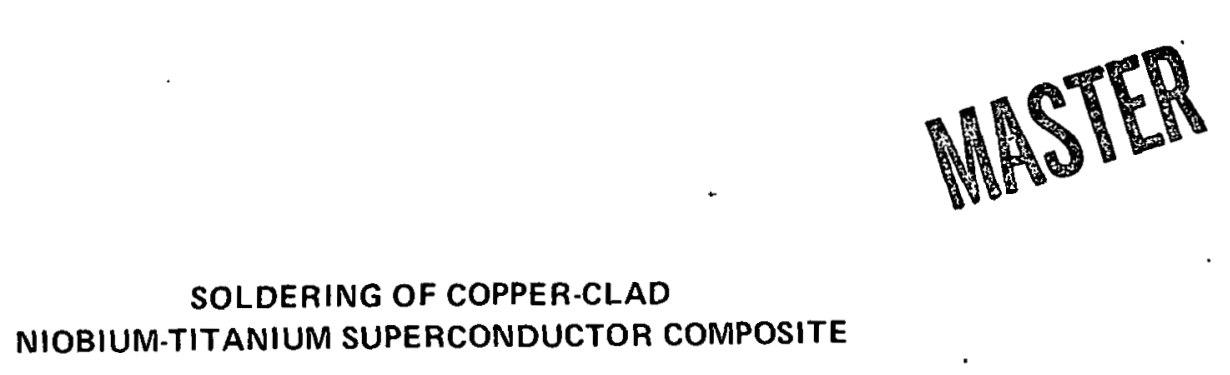
A. J. Moorhead
J. J. Woodhouse
D. S. Easton

Date Published: April 1977

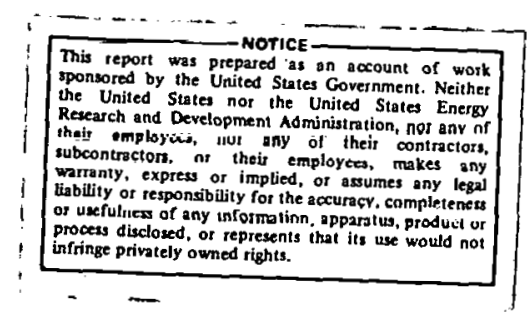

NOTICE This document contains information of a preliminary nature. It is subject to revision or correction and therefore does not represent a finâl repont.

Prepared by the OAK RIDGE NATIONAL LABORATORY

Oak Ridge, Tennessee 37830

operated by

UNION CARBIDE CORPORATION

for the

ENERGY RESSEARCH AND DEVELOPMENT ADMIN!!STRATION 
THIS PAGE

WAS INTENTIONALLY

LEFT BLANK 


\section{CONTENTS}

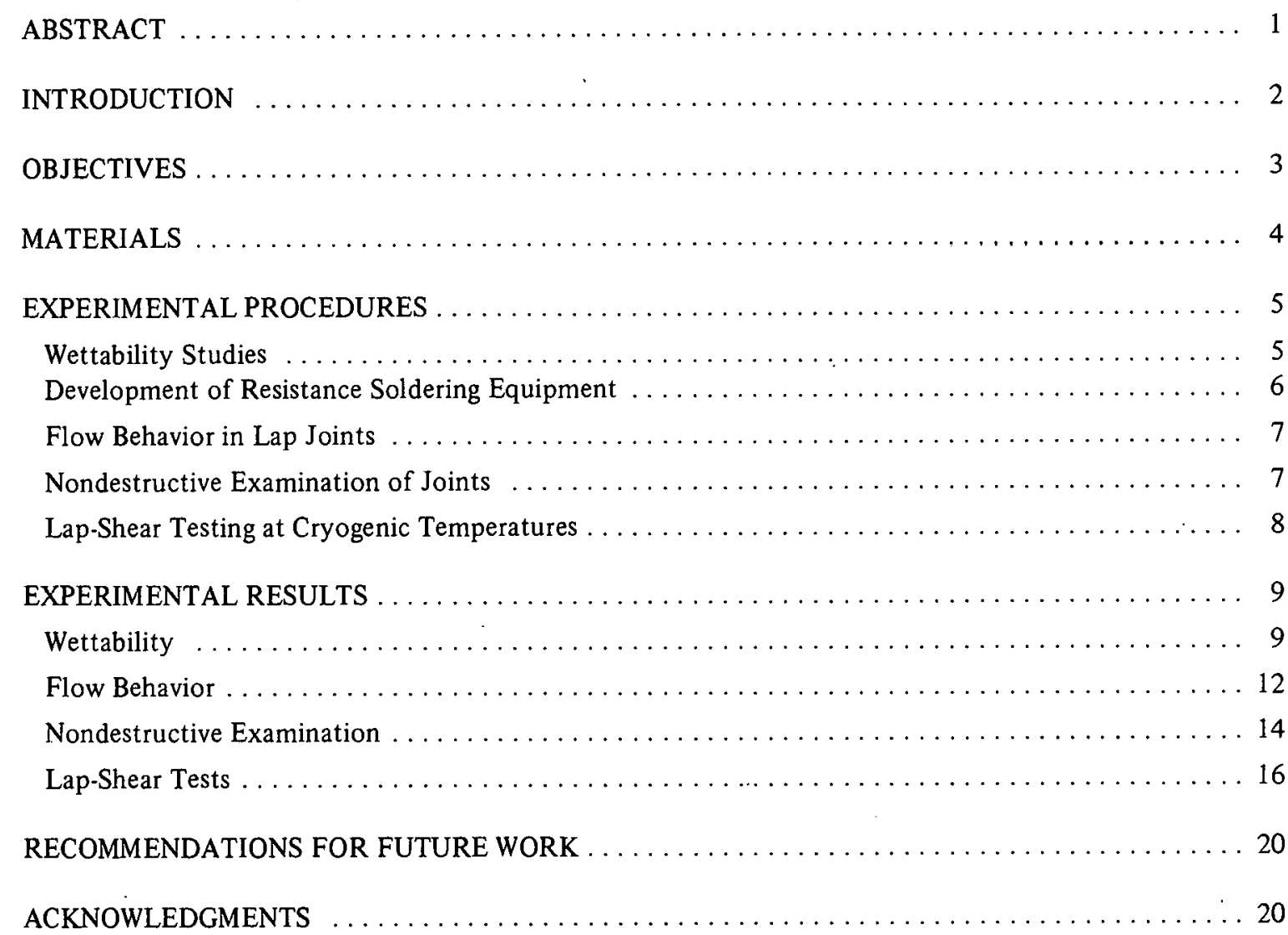




\title{
SOLDERING OF COPPER-CLAD NIOBIUM-TITANIUM SUPERCONDUCTOR COMPOSITE
}

\author{
A. J. Moorhead \\ J. J. Woodhouse \\ D. S. Easton
}

\begin{abstract}
When superconductivity is applied to various electrical devices, the joining of the superconducting material and the performance of the joints are generally crucial to the successful operation of the system. Although many techniques are being considered for joining composite superconductors, soldcring is the most coninion. We determined the wetting and flow behavior of various solder and flux combinations on a copper-clad $\mathrm{Nb}$-Ti composite, developed equipment and techniques for soldering and inspection of lap joints, and determined the shear strength of joints at temperatures down to $-269^{\circ} \mathrm{C}(4 \mathrm{~K})$. We studied 15 solders and 17 commercial and experimental fluxes in the wettability and flow tests. A resistance unit was built for soldering test specimens. A series of samples soldered with $80 \mathrm{~Pb}-20 \mathrm{Sn}, 83 \mathrm{~Pb}-15 \mathrm{Sn}-2 \mathrm{Sb}, 97.5 \mathrm{~Pb}-1.5 \mathrm{Ag}-1 \mathrm{Sn}, 80 \mathrm{In}-15 \mathrm{~Pb}-5 \mathrm{Ag}$, or $25 \mathrm{In}-37.5$ $\mathrm{Pb}-37.5 \mathrm{Sn}$ (wt \%) was inspected by three nondestructive techniques. Through-transmission ultrasound gave the best correlation with nonbond areas revealed in peel tests. Single-lap shear specimens soldered with $97.5 \mathrm{~Pb}-1.5 \mathrm{Ag}-1 \mathrm{Sn}$ had the highest strength (10.44 ksi, $72 \mathrm{MPa}$ ) and total elongation (0.074 in., $1.88 \mathrm{~mm})$ at $-269^{\circ} \mathrm{C}(4 \mathrm{~K})$ of four solders tested.
\end{abstract}




\section{INTRODUCTION}

Currently, large efforts are under way in this energy-conscious world in the application of superconductivity to various electrical devices or systems. These include magnetic levitation systems for high-speed ground transportation, ${ }^{1,2}$ long-range power transmission cables, ${ }^{3,4}$ electrical generators, ${ }^{5,6}$ conductor windings for magnetohydrodynamic magnets, ${ }^{7}$ energy storage systems, ${ }^{8}$ and plasma confinement for nuclear-fusion power generators. ${ }^{9}$ Generally, the joining of the superconducting material and the integrity, electrical resistivity, and strength of the joints are critical to the success of the application. In most cases to date, the systems have been small enough that the number of joints has been liniled. The design and location of such joints have been relatively simple; that is, there was adequate space to allow the joint to be located in a noncritical area (outside the windings in the case of a magnet) and to be reinforced by clamps, rivets, or other mechanical devices. However, there are plans ${ }^{9}$ for building very large machines to demonstrate the feasibility of obtaining power economically from a thermonuclear fusion reactor. Superconducting toroidal field coils are to be used tor magnetıc confinement of the plasma in these devices. These coils, which will be about $7 \mathrm{~m}(23 \mathrm{ft})$ in diameter, will require many kilometers of superconducting windings. The superconducting materals under consideratlon for these cuils alte cuntpusites consisting of either $\mathrm{Nb}$-Ti or $\mathrm{Nb}_{3} \mathrm{Sn}$ filaments in a matrix of either copper or aluminum.

Because of the complex nature of these cunnusiles, insufficient lênithis to wind a largc coil can presently be fabricated. Thus, a number of joints between cunductors will be required. Thesc joints must be able to withstand large mechanical forces from winding prestress, thermal contraction during cool-down to the cryogenic temperatures necessary for superconductivity, and magnetic-field stresses. In addittorl, lhey must be ahle to carry the large electrical currents normally carried by the superconductor without excessive heating. The work discussed in this paper focuses on the development of techniques for joining (by soldering) superconductor composite material into lengths for winding into large magnet coils, the development of nondestructive examination techniques, and the determination of the mechanical properties, at cryogenic temperatures, of the joints so produced.

1. C. Albrecht et al., "Superconducting Levitated Systems: First Results With the Experimental Facility at Erlangen," pp. 28-34 in Proc. 5th Int. Cryog. Eng. Conf., Kyoto, 1974, ed. K. Mendelssohn, IPC. Science and Technology Press, Kent, England, 1974.

2. R. D. Thornton, Y. Iwasa, and H. H. Kolm, "l'he Màgneplane System," pp. $42-4 j$ in Rrut. 5th Iht. Cryog. Eng. Conf., Kyoto, 1974, ed. K. Mendelssohn, IPC Science and Technology Press, Kent, England, 1974.

3. G. Bogner, "Cryopower Transmission Studies in Europe," pp. 54-63 in Proc. Sth Int. Cryog. Eng. Conf., Kyoto, 1974, ed. K. Mendelssohn, IPC Science and Technology Press, Kent, England, 1974.

4. R. W. Meyerhoff, "Superconducting Power Transmission," pp. 433-58 in The Science and Technology of Superconductivity, vol. 2, ed. W. D. Gregory et al., Plenum, New York, 1973.

5. J. L. Kirtley, Jr., et al., "MIT-EEI Program un! Jare 5uprercinducting Machinos." pp. 1282 ...86 in IEEE Trans. Power Appar. Systems, vol. PAS-92, No. 4 (July/August 1973).

6. R. D. Blaugher et al., A High Speed Superconducting Generator, Westinghouse Research Report 74-8J2-SCGEN-P1 (July 1974).

7. Y. Aiyama et al., "A Large Superconducting MHD Magnet," pp. 300-303 in Proc. Sth Int. Cryog. Eng. Conf., Kyoto, 1974, ed. K. Mendelssohn, IPC Science and Technology Press, Kent, England, 1974.

8. R. W. Boom et al., "Magnet Design for Supercunductive Eneıgy Storage for Powcr Systoms," pp. 177-83 in Proc. Sth Int. Conf. Magn. Technol. Mr'-5, Rome, April 1975, ed. N. Sacchelti et dl., Laboratori Nazionali del CNEN, Frascati, I taly, July 1975.

9. M. S. Lubell, "Superconducting Toroidal Magnets for Fusion Feasibility Experiments and Power Reactors," pp. 164-73 in Proc. 5th Int. Cryog. Conf. Kyoto, 1974, ed. K. Mendelssohn, IPC Science and Technology Press, Ltd., Kent, England, 1974. 
Although many alternate techniques are being studied for joining superconductor composites (e.g., ultrasonic, ${ }^{10}$ electron beam, ${ }^{11}$ explosion, ${ }^{12}$ and resistance-spot ${ }^{13}$ welding), soldering is still the most common $^{14-16}$ method. Soldering has the advantages of requiring limited capital investment for equipment or facilities; is amenable to making joints in situ; and is a simple, familiar process to magnet-winding personnel. In addition, by proper selection of solders, the operation can be conducted below the temperature at which the superconducting properties of the composites are degraded. This temperature, which must not be exceeded, differs for various superconductors but is near $350^{\circ} \mathrm{C}\left(662^{\circ} \mathrm{F}\right)$.

Soldering also has some limitations and disadvantages, the most evident being that joints are generally weaker than the base materials. Solder joints must normally have some type of lap rather than butt configuration, perturbating the windings of the magnet for those joints that fall within the coil. Another limitation is that the soldered joint is not superconducting (at least in the presence of strong magnetic fields), although resistances of the order of $10^{-7}$ to $10^{-8} \Omega$ are obtainable. A final disadvantage of soldering is that it requires careful procedures to avoid flux entrapment and potential corrosion problems.

Although soldering has been widely used to join superconducting materials, there is a notable lack of published data on the mechanical and physical properties of these joints. There are data on the cryogenic properties of solder wires themselves, ${ }^{17,18}$ but we have been unable to find any on the properties of actual soldered joints in superconductor composites. This lack of data on joints is probably due to the facts that (1) mechanical testing of actual joints is complicated by the variables of flux, time-temperature cycle, joint thickness, and base material properties; and (2) fabricators of magnet coils consider the property data to be either proprietary or not sufficiently complete to publish in the open literature. Admittedly, the concerns expressed in the first instance are valid; however, the exchange of information on actual solder joints (with careful description of the various procedural variables and conditions) can only lead to further understanding of, confidence in, and use of this process for fabrication of superconducting devices.

\section{OBJECTIVES}

The objectives of this study were as follows: (1) to determine the wetting and flow behavior of a wide range of solder and flux combinations on a copper-clad superconductor and on the Nb-Ti filaments themselves, (2) to conduct a feasibility study on the use of the resistance-soldering process for making joints in superconducting composites, (3) to evaluate several nondestructive techniques for inspection of

10. J. W. Hafstrom et al., "Joining Nb-Ti Superconductors by Ultrasonic Welding," paper presented at the Appl. Supercond. Conf., Palo Alto, Calif., August 1976.

11. L. Damicone, Sciaky Brothers, Inc., Chicago, Ill. private communication to R. L. Brown, Thermonuclear Division, Oct. 14, 1975.

12. D. N. Cornish, J. P. Zbasnik, and H. E. Pattee, Explosive Joints in Nb-Ti/Cu Composite Superconductors, UCRL-77241 (November 1975).

13. G. Luderer, P. Dullenkop, and G. Laukien, "Superconducting Joint Between Multifilamentary Wires," Cryogenics 14(9), 518-19 (September 1974).

14. J. R. Purcell and P. G. Marston, The Superconducting Magnet System for the Argonne 12-Foot Bubble Chamber, ANL/HEP 6813 (June 1968).

15. D. L. Atherton and R. Stevenson, "A 75 KG $41 \mathrm{~cm}$ Bore Continuous Disk Wound NbTi Superconducting Magnet," Cryogenics 14(3), 164-66 (March 1974).

16. M. Berthet, "Three Superconducting Magnets Differing in Conception and Operating Temperature," pp. 209-13 in Proc. 4th Int. Cryog. Eng. Conf., Eindhoven, May 1972, IPC Science and Technology Press, Kent, England, 1972.

17. J. L. Christian and J. F. Watson, The Tensile and Shear Properties of Several Solders at Cryogenic Temperatures, SAE-595E (October 1962).

18. H. S. Kalish and F. J. Dunkerley, "The Low Temperature Properties of Tin and Tin-Lead Alloys," AIME Tech. Publ. 2442 (September 1948). 
soldered joints, and (4) to determine the cryogenic (to $4 \mathrm{~K}$ ) lap-shear strengths of soldered joints as a function of procedural variables. This program did not include the measurement of resistivity of the joints and was limited to a single type of superconductor and solder joint, that is, a lap joint with tapered conductor ends.

\section{MATERIALS}

The composite used in this investigation was a 1 -mm-thick $\times 9.9$-mm-wide $(0.04 \times 0.39$ in. $)$ ribbon of copper containing 84 filaments of an $45 \mathrm{Nb}-55 \mathrm{Ti}$ (wt \%) superconductor. The actual composite rather than a plain copper strip was used in all phases of this program including the preliminary wetting and flow tests, since soldering is such a surface-related phenomenon and all coppers would not be expected to be wet exactly the same. A cross section of the composite, which is made by coextrusion and subsequent drawing and rolling of a copper billet containing $\mathrm{Nb}$-Ti rods, is shown in Fig. 1.

A large number of solder-flux combinations were investigated for their ability to wet both the copper matrix and the Nb-Ti filaments. The solders tested in this portion of the program are given in Table 1 . A wide range of commercial tin-lead solders was chosen (to include both those with high and low tin contents), as well as a number of commercial indium-bearing or -base alloys. Eleven commercial fluxes were studied in the wettability and flow portions of the program. However, to evaluate more systematically the merits of specific fluxing agents recognized in the soldering industry, it was subsequently decided to use nonproprietary fluxes of known composition (Table 2).

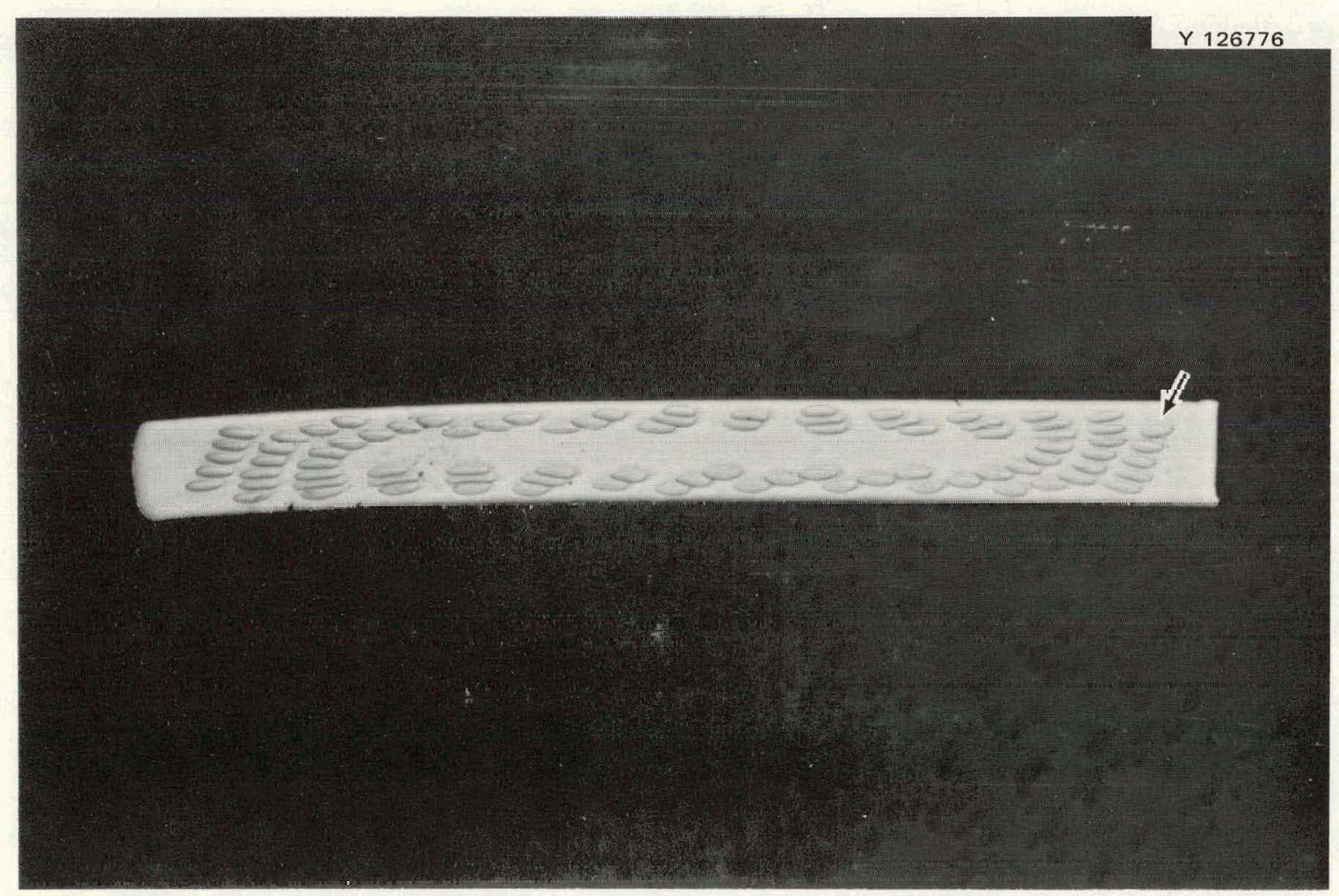

Fig. 1. Metallographic cross section of copper-clad $\mathrm{Nb}$-Ti superconductor ribbon. One of the $\mathrm{Nb}-\mathrm{Ti}$ filaments is indicated by an arrow. 
Table 1. Solders evaluated for joining of copper-clad $\mathrm{Nb}$-Ti superconductor ribbon

\begin{tabular}{|c|c|c|c|c|c|}
\hline $\begin{array}{c}\text { Alloy } \\
\text { designation }\end{array}$ & $\begin{array}{c}\text { Composition } \\
\text { (wt \%) }\end{array}$ & $\begin{array}{l}\text { Solidus } \\
\left({ }^{\circ} \mathrm{C}\right)\end{array}$ & $\begin{array}{c}\text { Melting } \\
\text { point } \\
\left({ }^{\circ} \mathrm{C}\right)\end{array}$ & $\begin{array}{l}\text { Liquidus } \\
\left({ }^{\circ} \mathrm{C}\right)\end{array}$ & $\begin{array}{c}\text { Dipping } \\
\text { temp } \\
\left({ }^{\circ} \mathrm{C}\right)\end{array}$ \\
\hline A & $95 \mathrm{Sn}-5 \mathrm{Ag}$ & 221 & & 245 & $275-325$ \\
\hline B & $80 \mathrm{~Pb}-20 \mathrm{Sn}$ & 183 & & 280 & $290-320$ \\
\hline $\mathrm{C}$ & $83 \mathrm{~Pb}-15 \mathrm{Sn}-2 \mathrm{Sb}$ & 183 & & 275 & $315-320$ \\
\hline $\mathrm{D}$ & $97.5 \mathrm{~Pb}-1.5 \mathrm{Ag}-1 \mathrm{Sn}$ & & 309 & & 345 \\
\hline $\mathrm{E}$ & $60 \mathrm{Sn}-40 \mathrm{~Pb}$ & 183 & & 190 & $205-275$ \\
\hline $\mathrm{I}-1$ & $50 \mathrm{In}-50 \mathrm{Sn}$ & 117 & & 125 & 150 \\
\hline $\mathrm{I}-2$ & 80 In- $15 \mathrm{~Pb}-5 \mathrm{Ag}$ & & 149 & & 175 \\
\hline $\mathrm{I}-3$ & $90 \mathrm{In}-10 \mathrm{Ag}$ & 141 & & 238 & $260-275$ \\
\hline $\mathrm{I}-4$ & $100 \mathrm{In}$ & & 157 & & 190 \\
\hline I-5 & $25 \mathrm{In}-37.5 \mathrm{~Pb}-37.5 \mathrm{Sn}$ & 134 & & 181 & 205 \\
\hline I-6 & $4.76 \mathrm{In}-92.86 \mathrm{~Pb}-2.38 \mathrm{Ag}$ & & 283 & & 345 \\
\hline $\mathrm{I}-7$ & $50 \mathrm{In}-50 \mathrm{~Pb}$ & 180 & & 209 & 245 \\
\hline $\mathrm{I}-8$ & $44 \mathrm{In}-42 \mathrm{Sn}-14 \mathrm{Cd}$ & & 93 & & 150 \\
\hline$I-9$ & $12 \mathrm{In}-70 \mathrm{Sn}-18 \mathrm{~Pb}$ & & 162 & & 260 \\
\hline $\mathrm{I}-10$ & $25 \mathrm{In}-75 \mathrm{~Pb}$ & 227 & & 264 & 285 \\
\hline
\end{tabular}

Table 2. Experimental fluxes evaluated for joining of copper-clad $\mathrm{Nb}$-Ti superconductor ribbon

\begin{tabular}{|c|c|}
\hline Designation & Formulation \\
\hline 1 & Dimethylamine hy drochloride $(\mathrm{DMA} \cdot \mathrm{HCl})$ \\
\hline 2 & $\begin{array}{l}7 \mathrm{nCl}_{2}, 383 \mathrm{~g} \\
\mathrm{NH}_{4} \mathrm{Cl}, 38 \mathrm{~g} \\
\mathrm{HCl}, 40 \mathrm{ml} \\
\mathrm{H}_{2} \mathrm{O}, 10 \mathrm{ml}\end{array}$ \\
\hline 3 & $\begin{array}{l}\mathrm{ZnCl}_{2}, 33.7 \mathrm{~g} \\
\mathrm{NH}_{4} \mathrm{Cl}, 3.8 \mathrm{~g} \\
\mathrm{H}_{2} \mathrm{O}, 100 \mathrm{ml}\end{array}$ \\
\hline 4 & Glycerine $+1 \mathrm{wt} \% \mathrm{DMA} \cdot \mathrm{HCl}$ \\
\hline 5 & Rosin +0.2 wt $\% \mathrm{DMA} \cdot \mathrm{HCl}$ \\
\hline 6 & Rosin $+1.0 \mathrm{wt} \%$ DMA $\cdot \mathrm{HCl}$ \\
\hline
\end{tabular}

EXPERIMENTAL PROCEDURE

\section{Wettability Studies}

In order to study the largest number of solder-flux combinations in the shortest period of time, we used a dip-tinning test to evaluate wettability. In this test a small alumina crucible containing solder was held at a constant temperature, and short lengths of flux-covered composite were immersed in the molten bath as illustrated in Fig. 2. A thermocouple was used to monitor the temperature of the solder. All samples were precleaned by abrading with fine steel wool followed by wiping with acetone. In each case, one surface of the copper matrix was removed by filing to expose the $\mathrm{Nb}$-Ti filaments. Thus, each dipping test gave an indication of the wetting bchavior of a given solde-flux combination (at a specific temperature) on hoth 


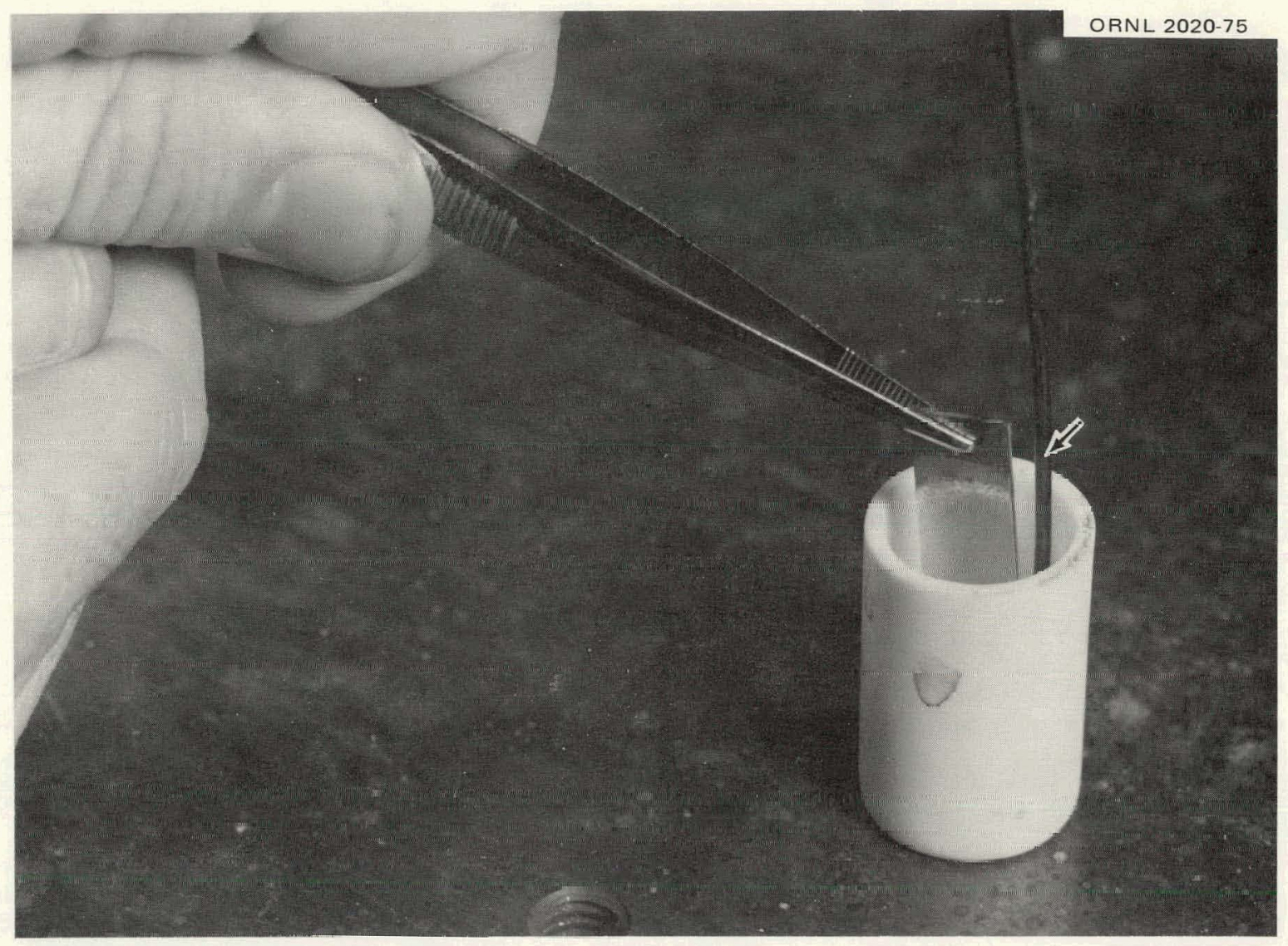

Fig. 2. Dip-tinning of superconductor strip in a crucible containing molten solder. The arrow indicates the sheath-type thermocouple used to monitor solder temperatures.

the copper matrix and the $\mathrm{Nb}$-Ti filaments. This latter information would be important in the case of joints (such as a scarf joint) in which the superconductor filaments would be exposed. A scarf joint has the advantage over the lap joint in that the scarf does not introduce an offset in the coil during winding. However, scarf joints are not widely used, since it is difficult to get enough overlap in a scarf joint to develop joint strength equal to composite strength, and the joints are more difficult to prepare than a simple lap joint.

\section{Development of Résistance Soldering Equipment}

In order to facilitate the rapid heating and cooling of actual solder joints (to minimize the time required per specimen), the simple resistance soldering unit shown in Fig. 3 was built. This device provides heating of the joint as the result of resistance to the passage of a high-amperage, luw-voltage current through a set of graphite electrodes and the conductor strips. Pressure is applied to the interface by a pair of compression springs. Using this device with a current of the order of $600 \mathrm{~A}$ ac at $2 \mathrm{~V}$, it was possible to solder a joint (including cool-down) in less than $5 \mathrm{~min}$. 


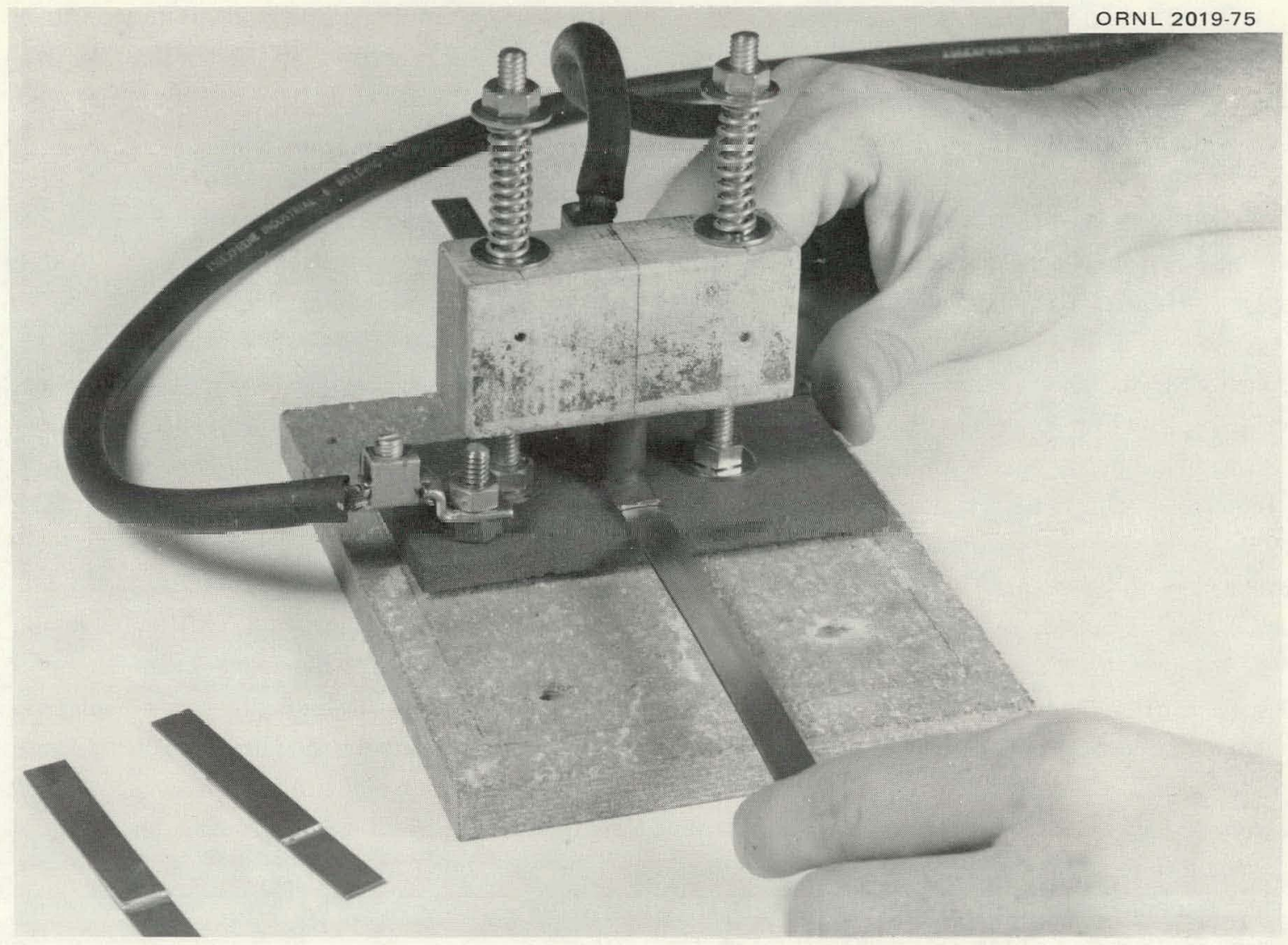

Fig. 3. Resistance-soldering unit with superconductor composite strips in position between the graphite electrodes.

Flow Behavior in Lap Joints

A number of lap joint specimens were subsequently soldered using the resistance-soldering unit to study the effect of various fluxes on the flow behavior of some of the solders which looked most promising in the dip-tinning tests. A specimen with $25 \mathrm{~mm}$ ( 1 in.) overlap was used with a short length of solder placed at one end of the joint in the fillet area. The distance of flow was measured for each solder-flux combination, and the wetting angle of one or both fillets (where flow occurred completely through the joint) was determined using a shadowgraph. We also studied the effects of soldering in a helium atmosphere in tests in which a low-temperature flux (e.g., rosin) was used with a high-melting solder. A glass bell jar was placed over the resistance-soldering unit, and helium gas was introduced, displacing the air. This technique has the advantage of allowing the use of a noncorrosive flux such as rosin for soldering above its normal service temperature.

\section{Nondestructive Examination of Joints}

Because the integrity of each of the joints (particularly those enclosed within the windings) in a magnet is so critical to the successful operation of the coil, the development of reliable techniques for nondestructive examination of the completed bonds is a vital part of the joining development effort. Solder 
joints are generally considered to be difficult to inspect nondestructively because any discontinuities tend to be planar (two dimensional) in nature. However, in view of the need for improved techniques, we conducted feasibility studies on inspection using three techniques - x-ray radiography, thermal imaging, and ultrasonic.

Radiography would normally be used primarily for bench inspection of joints prior to winding, although with specialized equipment (such as the rod-anode microfocus x-ray source being studied at ORNL) $)^{19}$ it might be possible to conduct in situ radiographic inspection of such joints as coil-to-coil splices. A series of ten soldered joints (two each soldered with $80 \mathrm{~Pb}-20 \mathrm{Sn}, 83 \mathrm{~Pb}-15 \mathrm{Sn}-2 \mathrm{Sb}, 97.5 \mathrm{~Pb}-1.5$ Ag-1 Sn, $80 \mathrm{In}-15 \mathrm{~Pb}-5 \mathrm{Ag}$, and $25 \mathrm{In}-37.5 \mathrm{~Pb}-37.5 \mathrm{Sn}$ ) were inspected by radiography. All samples were soldered by the same procedure (other than the variable of soldering temperature): (1) pretinning, using a soldering-iron heat source and flux No. 2 of Table $2\left(\mathrm{ZnCl}_{2}-\mathrm{NH}_{4} \mathrm{Cl}-\mathrm{HCl}-\mathrm{H}_{2} \mathrm{O}\right)$; (2) washing in hot tap water, rinsing in alcohol to remove flux residue; (3) resistance soldering, using no additional solder, but with a commercial activated rosin flux. Two sets of parameters were used for radiography, with type M film: (1) 200-kV accelerating potential, 10-mA current, 60-sec exposure, and 1370-mm (54-in.) film-to-source distance, with $0.13 \mathrm{~mm}(0.005 \mathrm{in}$.) of lead in front of the film and $0.25 \mathrm{~mm}(0.010 \mathrm{in}$.) behind; and (2) 100 $\mathrm{kV}, 15 \mathrm{~mA}, 180 \mathrm{sec}, 1420 \mathrm{~mm}$ (56 in.), with no lead in front of the film, but $0.25 \mathrm{~mm}(0.010$ in.) behind. The latter set of parameters was chosen because it produced an image with greater contrast.

Thermal evaluation of some solder joints was conducted using a commercial infrared-sensitive imaging system. Thermal imaging is one of the most useful tests for determining nonbonded areas in soldered and brazed joints, since it is sensitive to defects which are planar in a direction parallel to the surface. The test is conducted by passing a pulse of electrical current longitudinally through the joint. The temperature distribution in the sample is displayed on a cathode-ray tube - nonbond areas are revealed as "hot spots." This technique has been widely used at Oak Ridge National Laboratory for inspection of various components, including fuel-pin simulators for nuclear reactors. ${ }^{2 U}$

Some of the ten samples radiographically inspected were also evaluated for quality by various ultrasonic inspection techniques. Again, this inspection technique is sensitive to discontinuities which are thin in the direction of detection. We initially attempted to use a thickness gage system with both $2 \mathrm{U}-$ and $1 \mathrm{U}-\mathrm{MHz}$ transducers. However, we were unable to detect a lack of bond with this technique. Although these results might be improved through use of a lower-frequency transducer, this would probably produce an unacceptable decrease in sensitivity. Accordingly, a through-transmission ultrasonile technique was evaluated for its sensitivity to nonbond areas in soldered joints. Using a 5-MHz collimated sound beam, we were readily able to detect a $3.18-\mathrm{mm}(0.125$-in.) flat-bottomed hole at the bond line and detect lack-of-bond areas.

\section{Lap-Shear Testing at Cryogenic Temperatures}

A number of single-lap shear tests of specimens having the geometry sliuwn in fig. 4 were cunducted in air at room temperature and in liquid nitrogen or helium at $-196^{\circ} \mathrm{C}\left(-320^{\circ} \mathrm{F}\right)$ or $-269^{\circ} \mathrm{C}\left(-452^{\circ} \mathrm{F}\right)$ respectively. The air and liquid-nitrogen test samples were loaded in a universal testing machine, using the fixture shown in Fig. 5. For the liquid-nitrogen tests, this fixture was simply immersed in a Dewar of liquid

19. B. E. Foster et al., Feasibility Studies for Nondestructive Testing of Duplex Tube-to-Tubesheet Joints and Tubes for an LMFBR Steam Generator, ORNL-5094, pp. 2-8 (December 1975).

20. W. A. Simpson, Jr., S. D. Snyder, and K. V. Cook, Infrared Inspection and Characterization of Fuel-Pin Simulators, ORNL/NUREG/TM-55, to be published. 
ORNL-DWG $76-16573$
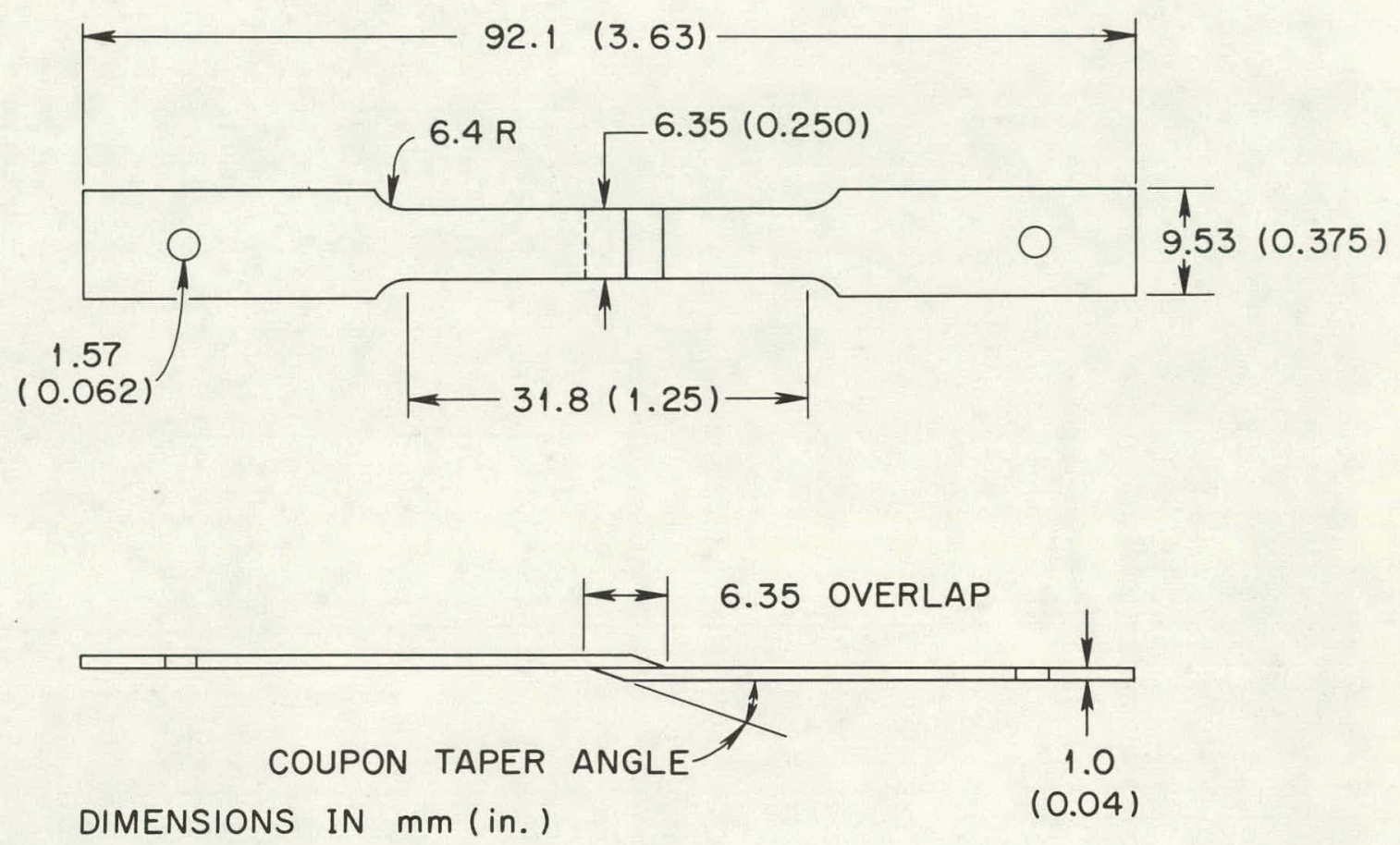

Fig. 4. Geometry of single-lap shear test specimen.

nitrogen; no extensometer was used. Elongation was taken as the total movement of the crosshead at failure of the joint; crosshead speed was $0.008 \mathrm{~mm} / \mathrm{sec}(0.02 \mathrm{in} . / \mathrm{min})$. The shear-strength data were computed on the basis of the load at failure divided by the overlap area.

The liquid-helium tests were conducted using the apparatus shown in Fig. 6. This device was inserted into a 10-cm-ID (4-in.) multiple-jacketed cryostat containing liquid helium. Again, crosshead speed was $0.008 \mathrm{~mm} / \mathrm{sec}(0.02 \mathrm{in} . / \mathrm{min})$. Strain measurements were obtained for some samples by a clip-on extensometer. These samples were not pulled to failure in order to avoid the possibility of damaging the extensometer. For the majority of tests the total elongation of the sample at failure was determined by crosshead movement.

Two other variables were included in the cryogenic properties study in addition to the effect of solder composition. One series of samples differed in the soldering technique used - pretinning vs direct soldering. Another group of specimens had coupons with end tapers of either 15,30 , or $45^{\circ}$ to determine the effect of that variable on mechanical properties.

\section{EXPERIMENTAL RESULTS}

\section{Wettability}

The results of the wettability study were promising from the standpoint of soldering of the copper matrix material, but very discouraging from the standpoint of wetting of the Nb-Ti superconductor 


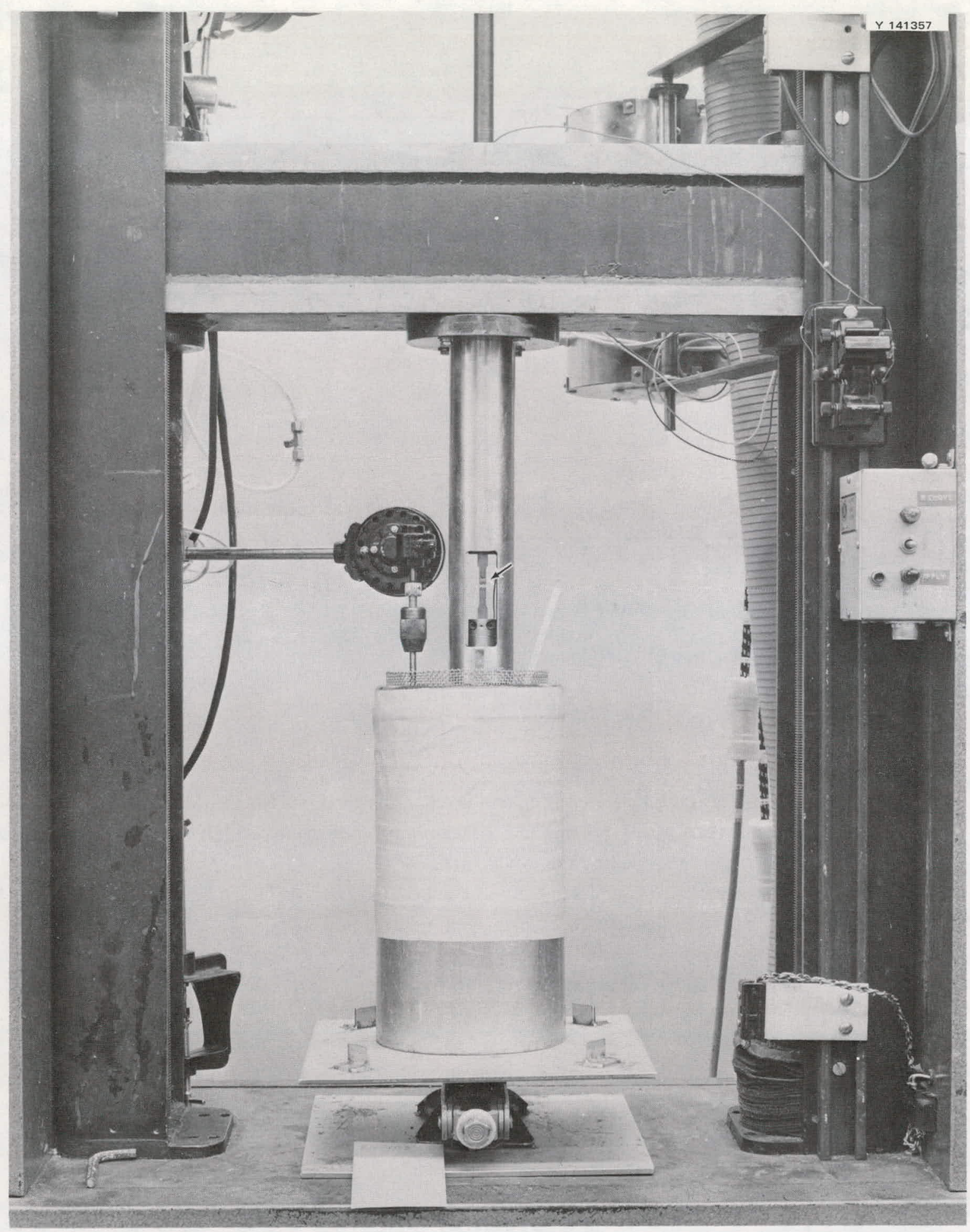

Fig. 5. Fixture head for lap-shear tests at room and liquid-nitrogen temperatures. 


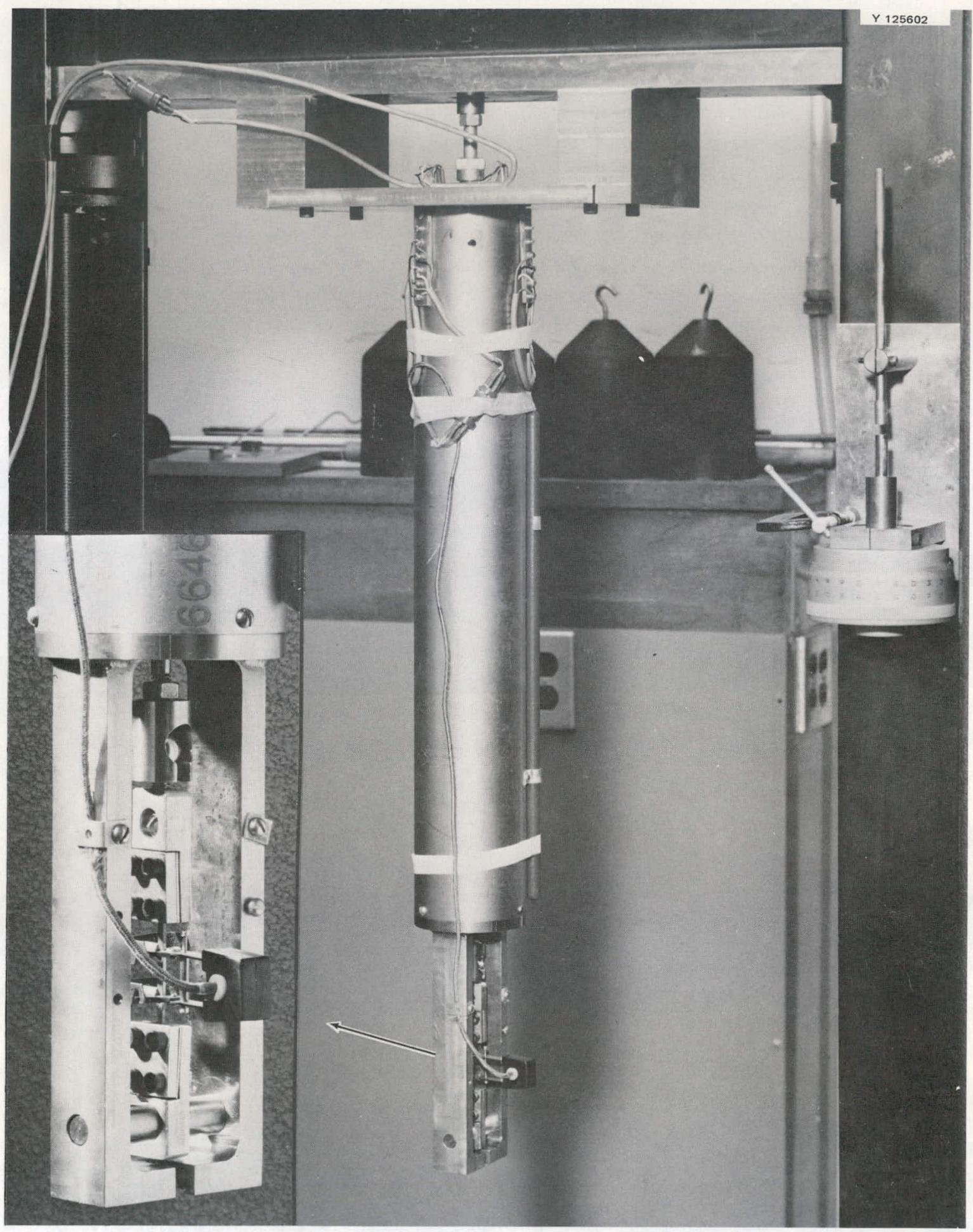

Fig. 6. Apparatus used in lap-shear tests in liquid helium. 
filaments themselves. The results shown in Fig. 7 are typical for this study. Note that in each case the solder wets the copper matrix, but does not wet the Nb-Ti filaments. Most of the solders readily wet the matrix when used in combination with most of the commercial and experimental fluxes. The general wetting behavior was such that it was difficult in a qualitative study of this type to select a group of fluxes and solders which clearly had such superior wetting behavior that they merited further evaluation. Since quantitative equipment was not available for measuring the rate at which solder wets a substrate, ${ }^{21}$ it was necessary to select a group of solders and fluxes for the flow tests in a somewhat arbitrary manner. Selection was on wetting behavior, published strength data (on solder wire), and on our desire to have tin-lead solders with high and low tin contents (as mentioned previously, it was important to determine the influence of tin on ductility at cryogenic temperatures). In addition, indium-containing solders were included for comparison with the tin-lead alloys. Accordingly, six alloys and three fluxes were predominantly studied for flow behavior during resistance soldering.

\section{Flow Belıvior}

Some of the flow test specimens for two different solder compositions are shown in Fig. 8. Several observations can be made concerning these solder joints. Note that the commercial flux designated as G.S. promotes a better (smaller) wetting angle with both solders than does the activated rosin flux (also commercially made). The addition of a helium atmosphere during soldering gave somewhal mixed results. It reduced oxidation of the flux and superconductor strip, as seen by comparing the specimens soldered with activated rosin flux in Fig. 8. However, the effect on wetting angle appears to vary according to flux composition, as shown by the data of Table 3 . The addition of helium when soldering with activated rosin flux resulted in most cases in a slight increase in wetting angle, that is, a decreased tendency for wetting the surface. Under the same conditions, bul with a commercial flux (designated G.S.), the wetting angle was generally the same or smaller (better wetting) in the helium environment. On the basis of these flowability

21. J. F. Shipley, "Influence of Hlux, Substrate and Solder Composition on Solder Wetting," Weld. J. 54, 357-62 (U)ctober 1975),

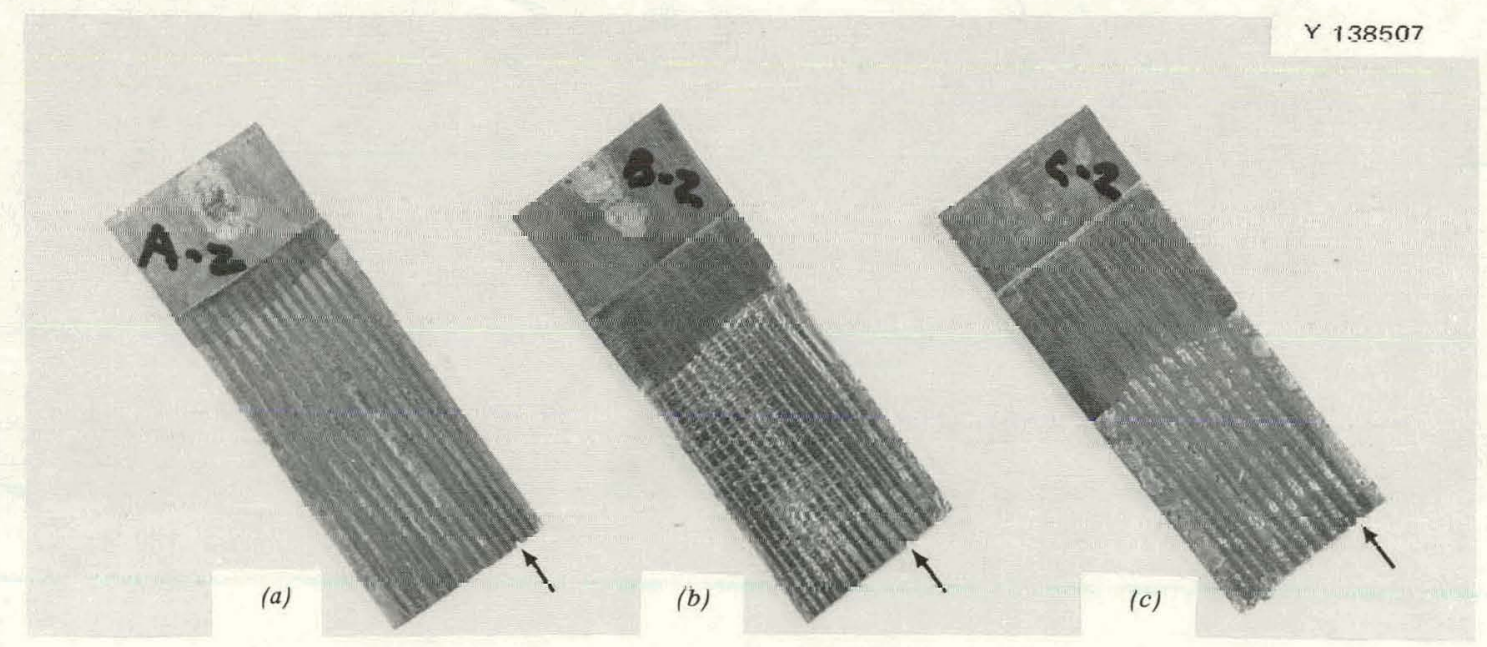

Fig. 7. Dip-tinned coupons with exposed Nb-Ti filaments (arrows). Note that in each case the solder has wet the copper matrix but not the superconductor itself. (a) $95 \mathrm{Sn}-5 \mathrm{Ag}$; (b) $80 \mathrm{~Pb}-20 \mathrm{Sn}$; (c) $83 \mathrm{~Pb}-15 \mathrm{Sn}-2 \mathrm{Sb}$. 


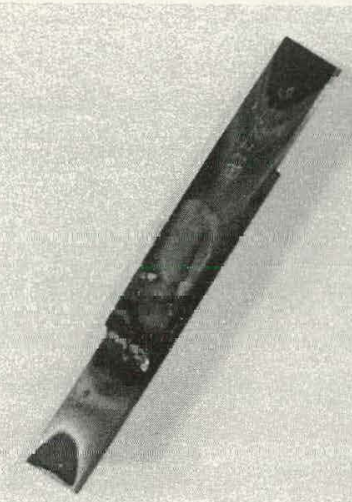

$30^{\circ}$

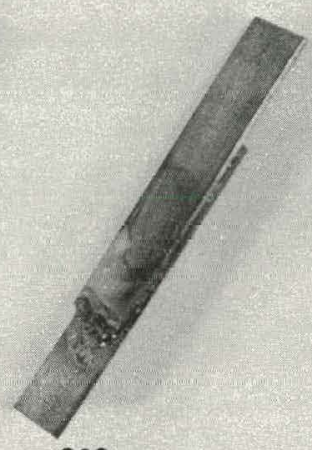

$30^{\circ}$

Activated Rosin

and

$\mathrm{He}$ Atmosphere

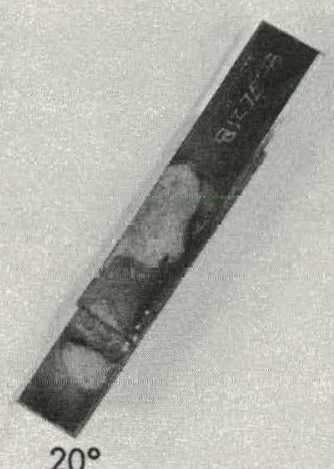

G. S. Flux

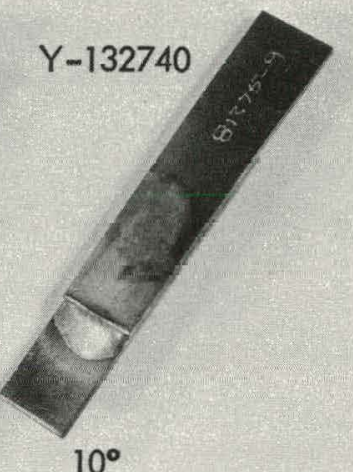

G. S. Flux

and

(a)

$$
\text { Rosin }
$$

He Atmosphere

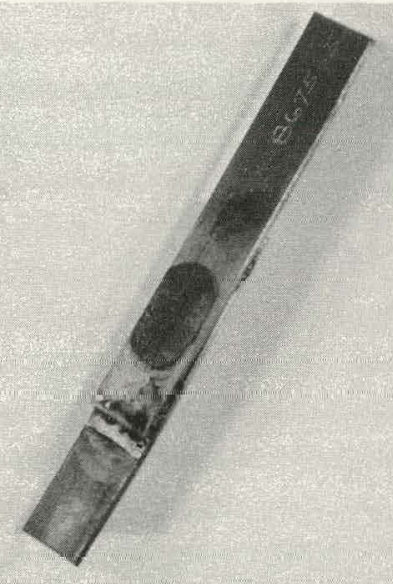

$20^{\circ}$

Activated Rosin and

$\mathrm{He}$ Atmosphere

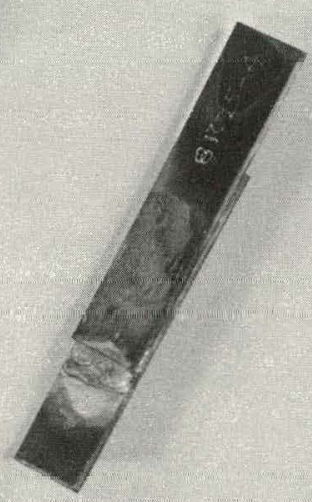

$15^{\circ}$

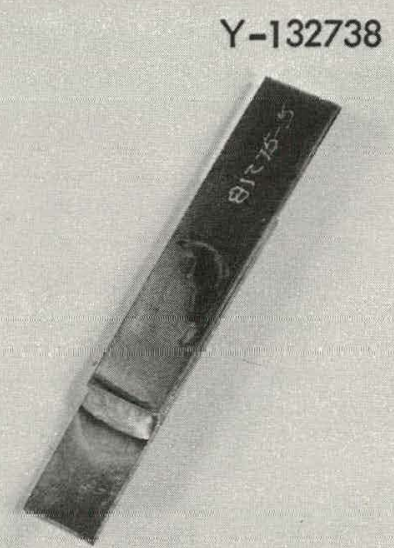

$15^{\circ}$ and

$\mathrm{He}$ Atmosphere

Fig. 8. Flowability specimens of copper-clad Nb-Ti superconductor composite resistance soldered using the solders, fluxes, and additional gas shielding noted. (a) Solder composition 97.5 Pb-1.5 Ag-1.0 Sn; (b) solder composition $83 \mathrm{~Pb}-15$ Sn-2 Sb. 
Table 3. Wetting angle of various solders on copper-clad superconductor composite as a function of flux composition

\begin{tabular}{|c|c|c|c|c|}
\hline \multirow{2}{*}{$\begin{array}{c}\text { Solder } \\
\text { designation }\end{array}$} & \multirow{2}{*}{$\begin{array}{c}\text { Solder } \\
\text { composition } \\
\text { (wt \%) }\end{array}$} & \multirow{2}{*}{$\begin{array}{c}\text { Flux } \\
\text { designation }\end{array}$} & \multicolumn{2}{|c|}{$\begin{array}{l}\text { Wetting angle } \\
\text { (degrees) }\end{array}$} \\
\hline & & & $\mathrm{F} 1^{a}$ & $\mathrm{~F} 2^{b}$ \\
\hline A & $95 \mathrm{Sn}-5 \mathrm{Ag}$ & $\begin{array}{l}\text { G.S. }{ }^{c} \\
\text { No. } 2^{e}\end{array}$ & $\begin{array}{l}10 \\
10\end{array}$ & $\begin{array}{l}d \\
40\end{array}$ \\
\hline B & $80 \mathrm{~Pb}-20 \mathrm{Sn}$ & $\begin{array}{l}\mathrm{AR}^{f} \\
\mathrm{AR}+\mathrm{He} \\
\text { G.S. } \\
\text { No. } 2\end{array}$ & $\begin{array}{l}10 \\
15 \\
10 \\
30\end{array}$ & $\begin{array}{l}d \\
20 \\
d \\
35\end{array}$ \\
\hline $\mathrm{C}$ & $83 \mathrm{~Pb}-15 \mathrm{Sn}-2 \mathrm{Sb}$ & $\begin{array}{l}\text { AR + He } \\
\text { G.S. } \\
\text { G.S. + He } \\
\text { No. } 2\end{array}$ & $\begin{array}{l}20 \\
15 \\
15 \\
10\end{array}$ & $\begin{array}{l}d \\
37 \\
25 \\
d\end{array}$ \\
\hline $\mathrm{D}$ & 97.5 Pb-1.5 Ag-1 Sn & $\begin{array}{l}\text { AR } \\
\text { G.S. } \\
\text { G.S. + He } \\
\text { No. } 2\end{array}$ & $\begin{array}{l}30 \\
20 \\
10 \\
10\end{array}$ & $\begin{array}{l}g \\
40 \\
d \\
30\end{array}$ \\
\hline $\mathrm{I}-2$ & $80 \mathrm{In}-15 \mathrm{~Pb}-5 \mathrm{Ag}$ & $\begin{array}{l}\text { AR } \\
\text { AR + He } \\
\text { G.S. } \\
\text { G.S. + He } \\
\text { No. } 2\end{array}$ & $\begin{array}{r}10 \\
15 \\
20 \\
20 \\
5\end{array}$ & $\begin{array}{l}40 \\
45 \\
30 \\
2.5 \\
30\end{array}$ \\
\hline$I-5$ & $25 \mathrm{In}-37.5 \mathrm{~Pb}-37.5 \mathrm{Sn}$ & $\begin{array}{l}\text { AR } \\
\text { AR + He } \\
\text { G.S. } \\
\text { No. } 2\end{array}$ & $\begin{array}{l}10 \\
15 \\
17 \\
20\end{array}$ & $\begin{array}{l}d \\
d \\
d \\
30\end{array}$ \\
\hline
\end{tabular}

${ }^{a}$ Fillet at which solder wire was placed prior to soldering.

${ }^{b}$ Fillet at end opposite to F1.

"A commercial "all metal, noncorrosive" tlux.

${ }^{d}$ Only pas tial fillet at end of juint.

e $383 \mathrm{~g} \mathrm{ZnCl}_{2}-38 \mathrm{~g} \mathrm{NH}_{4} \mathrm{Cl}-40 \mathrm{ml} \mathrm{HCl}-100 \mathrm{ml} \mathrm{H}_{2} \mathrm{O}$.

$f$ Activated rosin (commercial).

${ }^{g}$ Did not flow completely through $25 \mathrm{~mm}$ joint.

tests, the wettability tests, and the ease with which it is removed after soldering, the No. 2 flux ( $383 \mathrm{~g}$ $\mathrm{ZnCl}_{2}-38 \mathrm{~g} \mathrm{NH}_{4} \mathrm{Cl}-40 \mathrm{ml} \mathrm{HCl}-100 \mathrm{ml} \mathrm{H}_{2} \mathrm{O}$ ) was selected as the primary flux to be used in preparing specimens for the cryogenic property tests. This flux was greatly favored by the technician conducting the soldering tests and has the advantage of being of known composition so that it can be prepared in the laboratory.

\section{Nondestructive Examination}

The results of the radiographic inspection of a number of resistance-soldered lap joints were not encouraging. We found that although relatively thick voids in the solder could be detected by radiography, it was not sensitive to very thin areas of nonbond in which there was essentially metal-to-metal contact of the copper coupons. This result was confirmed by a series of specimens which were peeled apart after nondestructive examination, some of which are shown in Fig. 9. Note that nonbond areas (which were undetected by radiography) were found in each sample, independent of which solder is used. 

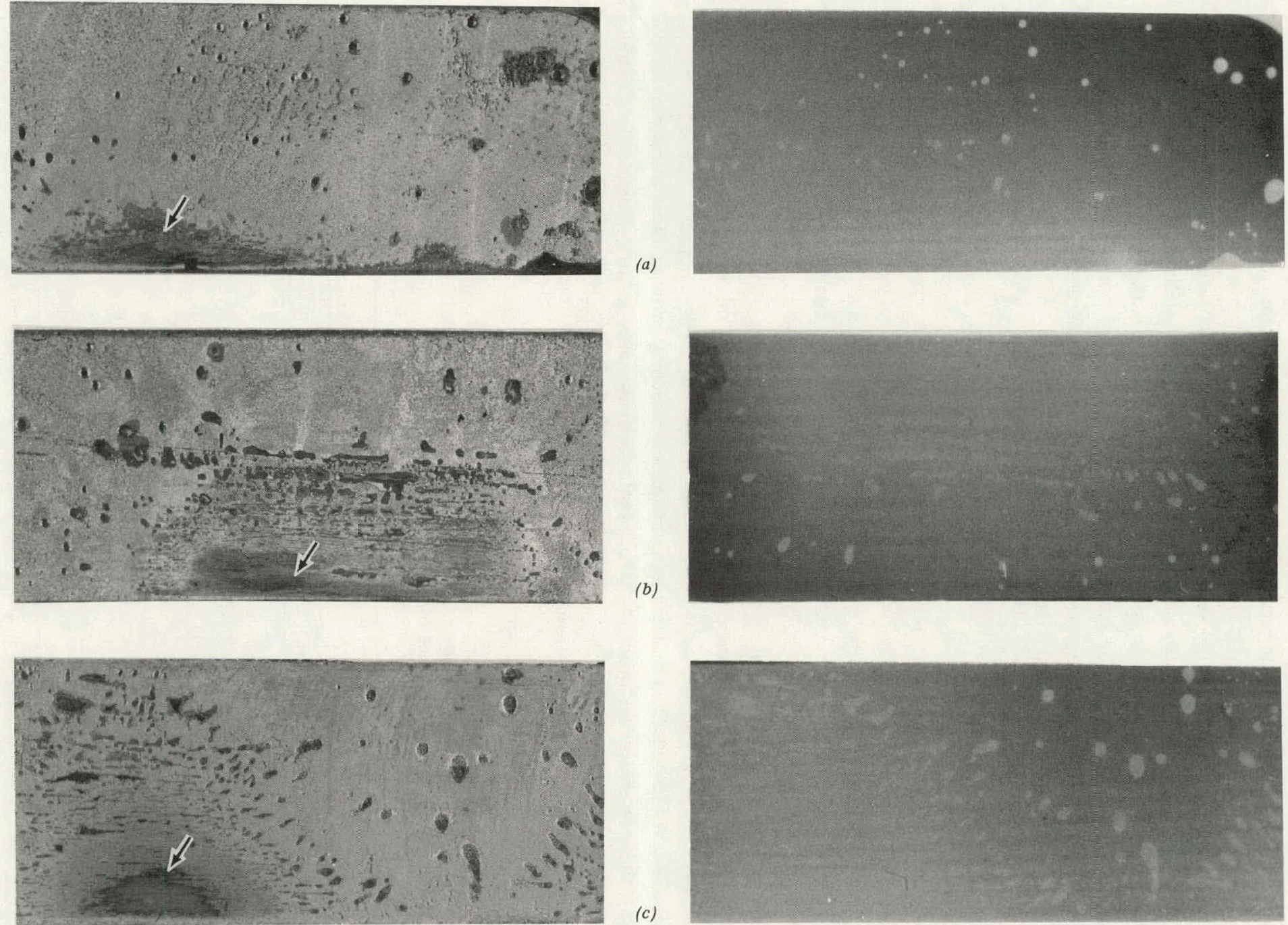

Fig. 9. Comparison of Photographs of faying surfaces of solder joints (left) after peel tests with positive frints of radiographic images (right) of the specimens prior to peeling. Note that there is good correlation except in the case of nonwetted copper areas (arrows), in which essentially metal-to-metal contact existed. The gray areas around many of the pores are the result of entrapped flux reacting vith moisture in the atmosphere after peeling. (a) Solder B- $80 \mathrm{~Pb}-2 \mathrm{C} \mathrm{Sn}$ : (b) solder D-97.5 Pb-1.5 Ag-1 Sn; (c) solder I5-25 In-37.5 Pb-37.5 Sn. 
Thermal evaluation of the quality of resistance-soldered joints in the superconductor composite was not possible due to the high thermal diffusivity of this material. A temperature difference caused by a nonbond was equalized so rapidly in the copper matrix that it exceeded the scanning capabilities of the infrared camera. Accordingly, the thermal evaluation technique is not suitable for examination of these materials, at least with the available equipment. However, it might be possible to develop other equipment with capabilities for detecting the very short temperature transients which occur in this composite.

Although we did not pursue the ultrasonic inspection process past a very preliminary stage, our tests do prove feasibility for use of the through-transmission ultrasound technique for detection of nonbond areas. A good correlation with unbonded areas in specimens which were peeled apart after inspection was found by use of a $5-\mathrm{MHz}$ unfocused transducer. The sensitivity of this technique could be greatly improved through the use of focused transducers and a modest developmental effort.

\section{Lap-Shear Tests}

The results of the single-lap shear tests conducted at room and cryogenic temperatures on resistance-soldered joints are given in ' lables 4 through 6 and in Fig. 10. 'lypical tested specimens are shown in Fig. 11. Table 4 gives the results of the study to determine if there was any significant difference in properties of those specimens which were pretinned using a soldering iron as compared with those soldered directly with no pretinning. Based on these results, we concluded that pretinned specimens had no apparent strength advantage; and there was the possible disadvantage of overheating the superconductor during pretinning, thereby harming its superconducting properties. Accordingly, the balance of the specimens soldered and tested in this program were of the direct-soldered, nontinned type.

The data for a series of specimens all soldered using the same procedure, but with different coupon taper angles (Table 5), indicate that small angles (e.g., $15^{\circ}$ ) result in significantly greater elongation at failure. The small number of samples tested and the scatter in the data make it difficult to draw conclusions as to the effect of coupon taper angle on shear strength.

Table 4. Comparison of shear test results for non-pretinned and pretinned copper clad $\mathrm{Nb} \mathrm{Ti}$ supereonduetor specimens soldered ${ }^{a}$ with $97.5 \mathrm{~Pb}-1.5 \mathrm{Ag}-1 \mathrm{Sn}$

\begin{tabular}{|c|c|c|c|c|c|c|}
\hline \multirow{2}{*}{ Sample } & \multicolumn{2}{|c|}{$\begin{array}{c}\text { Test } \\
\text { temperature }\end{array}$} & \multicolumn{2}{|c|}{$\begin{array}{c}\text { Shear } \\
\text { strength }^{b}\end{array}$} & \multicolumn{2}{|c|}{ Elongation $^{c}$} \\
\hline & ( $\mathrm{C})$ & (K) & (MPA) & (ksi) & (in.) & $(\mathrm{mm})$ \\
\hline \multicolumn{7}{|c|}{ Non-pretinned } \\
\hline 3 & 20 & 293 & 173 & 252 & $\cap 021$ & 053 \\
\hline $2+4^{d}$ & -196 & 77 & 29.8 & 4.32 & 0.083 & 2.1 \\
\hline \multicolumn{7}{|c|}{ Pretinned } \\
\hline $1+3$ & 20 & 293 & 18.8 & 2.73 & 0.032 & 0.81 \\
\hline $2+4$ & -196 & 77 & 27.2 & 3.95 & 0.054 & 1.37 \\
\hline
\end{tabular}

${ }^{a}$ Flux composition: $383 \mathrm{~g} \mathrm{ZnCl}_{2}-38 \mathrm{~g} \mathrm{NH}_{4} \mathrm{Cl}-40 \mathrm{ml} \mathrm{HCl}-100 \mathrm{ml} \mathrm{H}_{2} \mathrm{O}, 15^{\circ}$ coupon taper angle.

${ }^{b}$ Crosshead speed of $0.008 \mathrm{~mm} / \mathrm{sec}(0.02 \mathrm{in} . / \mathrm{min})$.

${ }^{c}$ Determined from crosshead movement.

${ }^{d}$ Properties shown are average of values for samples 2 and 4. 
Table 5. Effect of "coupon taper angle" on the properties at $-196^{\circ} \mathrm{C}$ of resistance-soldered joints ${ }^{a}$ in copper-clad $\mathrm{Nb}-\mathrm{Ti}$ superconductor composite

\begin{tabular}{lcccccc}
\hline \multirow{2}{*}{ Sample } & $\begin{array}{c}\text { Coupon } \\
\text { taper } \\
\text { angle }\end{array}$ & \multicolumn{2}{c}{ Shear strength $^{b}$} & & \multicolumn{2}{c}{ Elongation $^{c}$} \\
& $(\mathrm{MPa})$ & $(\mathrm{ksi})$ & & $(\mathrm{mm})$ & $($ in.) \\
\hline D-2 & $15^{\circ}$ & 26.4 & 3.83 & 1.37 & 0.054 \\
D-4 & $15^{\circ}$ & 33.1 & 4.81 & 2.11 & 0.083 \\
Av 2+4 & & 29.8 & 4.32 & & 1.74 & 0.069 \\
D-8 & $30^{\circ}$ & 10.3 & 1.49 & & 0.15 & 0.006 \\
D-9 & $30^{\circ}$ & 29.2 & 4.24 & 0.71 & 0.028 \\
Av 8+9 & & 19.8 & 2.87 & 0.43 & 0.017 \\
D-10 & $45^{\circ}$ & 38.4 & 5.57 & 0.84 & 0.033 \\
D-11 & $45^{\circ}$ & 33.0 & 4.79 & 0.48 & 0.019 \\
Av 10+11 & & 35.7 & 5.18 & 0.66 & 0.026 \\
\hline
\end{tabular}

${ }^{a}$ All specimens joined with $\mathrm{ZnCl}_{2}-\mathrm{NH}_{4} \mathrm{Cl}-\mathrm{HCl}-\mathrm{H}_{2} \mathrm{O}$ flux and $97.5 \mathrm{~Pb}-1.5$ Ag-1.0 Sn solder.

${ }^{b}$ Crosshead speed of $0.008 \mathrm{~mm} / \mathrm{sec}(0.02 \mathrm{in} . / \mathrm{min})$.

${ }^{c}$ Determined from crosshead movement.

Table 6. Summary of room-temperature and cryogenic shear-test data for soldered ${ }^{a}$ copper-clad $\mathrm{Nb}-\mathrm{Ti}$ superconductor

\begin{tabular}{|c|c|c|c|c|c|c|c|c|}
\hline \multirow{2}{*}{$\begin{array}{l}\text { Composition } \\
\text { (wt \%) }\end{array}$} & \multirow{2}{*}{ Sample } & \multicolumn{2}{|c|}{$\begin{array}{c}\text { Test } \\
\text { temperature }\end{array}$} & \multicolumn{2}{|c|}{ Shear Strength $^{b}$} & \multicolumn{2}{|c|}{$\begin{array}{c}\text { Total } \\
\text { elongation }\end{array}$} & \multirow{2}{*}{$\begin{array}{l}\text { Young's modulus } \\
\quad\left(\times 10^{6}\right) \text { (psi) }\end{array}$} \\
\hline & & $\left({ }^{\circ} \mathrm{C}\right)$ & $\overline{(\mathrm{K})}$ & $(\mathrm{MPa})$ & (ksi) & $(\mathrm{mm})$ & (in.) & \\
\hline $95 \mathrm{Sn}-5 \mathrm{Ag}$ & $\begin{array}{l}1+2^{d} \\
3+4 \\
5\end{array}$ & $\begin{array}{r}20 \\
-269\end{array}$ & $\begin{array}{r}293 \\
4\end{array}$ & $\begin{array}{l}40.3 \\
31.7\end{array}$ & $\begin{array}{l}5.85 \\
4.60\end{array}$ & $\begin{array}{l}0.81 \\
0.71\end{array}$ & $\begin{array}{l}0.032 \\
0.028\end{array}$ & 16.1 \\
\hline $80 \mathrm{~Pb}-20 \mathrm{Sn}$ & $\begin{array}{l}4+5 \\
1+2 \\
3\end{array}$ & $\begin{array}{r}20 \\
-269\end{array}$ & $\begin{array}{r}293 \\
4\end{array}$ & $\begin{array}{l}21.5 \\
52.5\end{array}$ & $\begin{array}{l}3.12 \\
7.62\end{array}$ & $\begin{array}{l}0.25 \\
1.11\end{array}$ & $\begin{array}{l}0.010 \\
0.044\end{array}$ & 15.1 \\
\hline 97.5 Pb-1.5 Ag-1 Sn & $\begin{array}{l}3 \\
2+4 \\
5+6 \\
7\end{array}$ & $\begin{array}{r}20 \\
-196 \\
-269\end{array}$ & $\begin{array}{r}293 \\
77 \\
4\end{array}$ & $\begin{array}{l}17.3 \\
29.8 \\
72.0\end{array}$ & $\begin{array}{r}2.52 \\
4.32 \\
10.44\end{array}$ & $\begin{array}{l}0.53 \\
1.75 \\
1.88\end{array}$ & $\begin{array}{l}0.021 \\
0.069 \\
0.074\end{array}$ & 13.0 \\
\hline $25 \mathrm{In}-37.5 \mathrm{~Pb}-37.5 \mathrm{Sn}$ & $\begin{array}{l}4+5 \\
1+2 \\
3\end{array}$ & $\begin{array}{r}20 \\
-269\end{array}$ & $\begin{array}{r}293 \\
4\end{array}$ & $\begin{array}{l}25.1 \\
61.5\end{array}$ & $\begin{array}{l}3.64 \\
8.92\end{array}$ & $\begin{array}{l}0.28 \\
1.09\end{array}$ & $\begin{array}{l}0.011 \\
0.043\end{array}$ & 8.1 \\
\hline
\end{tabular}

${ }^{a}$ Flux composition: $383 \mathrm{~g} \mathrm{ZnCl}_{2}-38 \mathrm{~g} \mathrm{NH}_{4} \mathrm{Cl}-40 \mathrm{ml} \mathrm{HCl}-100 \mathrm{ml} \mathrm{H}_{2} \mathrm{O}, 15^{\circ}$ coupon taper angle.

${ }^{b}$ Crosshead specd of $0.008 \mathrm{~mm} / \mathrm{sec}(0.02 \mathrm{in}$. $/ \mathrm{min}$.)

${ }^{c}$ Determined from crosshead movement.

${ }^{d}$ Average of values for samples 1 and 2 . 
ORNL-DWG 76-19351

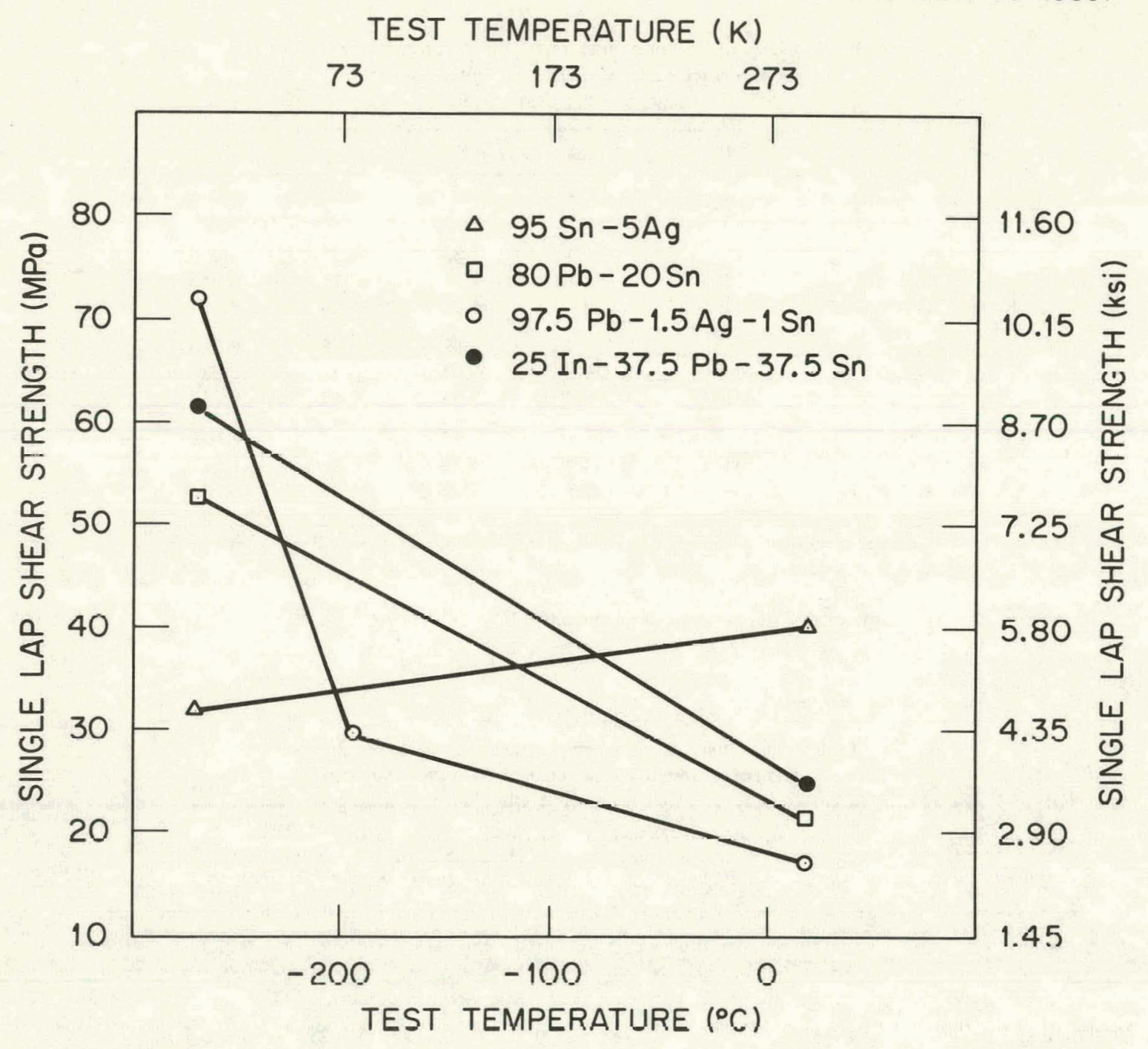

Fig. 10. Single-lap shear strength of resistance-soldered joints as a function of temperature and solder composition. Non-pretinned test specimens soldered using $\mathrm{ZnCl}_{2}-\mathrm{NH}_{4} \mathrm{Cl}-\mathrm{HCl}-\mathrm{H}_{2} \mathrm{O}$ flux. Crosshead speed of $0.0008 \mathrm{~mm} / \mathrm{sec}(0.02$ in./ $\mathrm{min})$.

Data comparing the shear strength of four solders at room and cryogenic temperatures are given in Table 6 and presented graphically in Fig. 10. These data indicate that all of the solders except the $95 \mathrm{Sn}-5$ $\mathrm{Ag}$ increase in strength and in ductility as the testing temperature is dropped to $-269^{\circ} \mathrm{C}(4 \mathrm{~K})$. There also appears to be a correlation between decreasing elongation with increasing tin content, indicating that high-tin alloys may not be the most suitable for service in a liquid-helium environment. This increase in elongation at low temperatures was not unexpected because copper (like other fcc materials) has been found to exhibit large increases in total elongation as the temperature is decreased. ${ }^{22}$ Note from Fig. 10 that the $97.5 \mathrm{~Pb}-1.5 \mathrm{Ag}-1 \mathrm{Sn}$ alloy exhibits the greatest strength at $-269^{\circ} \mathrm{C}$, although this material has the lowest strength at room temperature of the four solders tested.

22. D. A. Wigley, Mechanical Properties of Materials at Low Temperatures, p. 21, ed. K. Mendelssohn and K. D. Timmerhaus, Plenum, New York, 1971. 


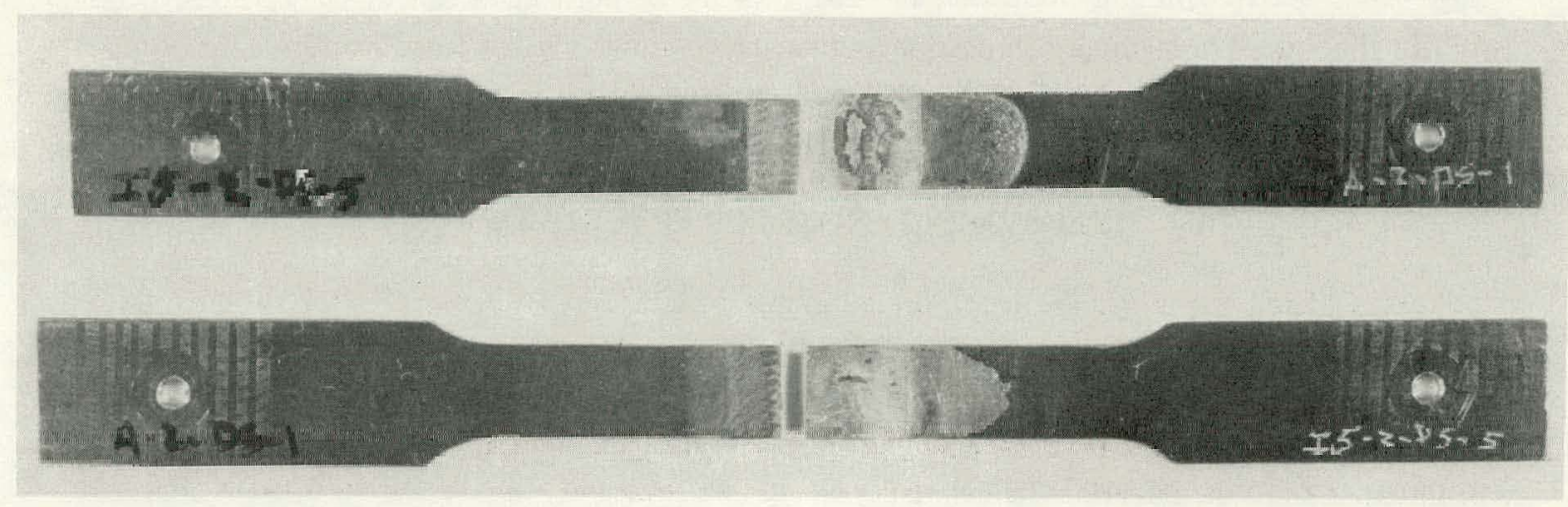

Fig. 11. Shear test specimens of copper-clad Nb-Ti superconductor composite.

The Young's modulus of elasticity for this particular superconductor composite is $110 \mathrm{GPa}\left(16 \times 10^{6}\right.$ psi). Table 6 shows that modulus values for the joints soldered with the $97.5 \mathrm{~Pb}-1.5 \mathrm{Ag}-1 \mathrm{~S}$ and $25 \mathrm{In}-37.5$ $\mathrm{Pb}-37.5 \mathrm{Sn}$ alloys are considerably luwer. The significance of these lower values is that yielding would tend to be concentrated in the solder joint rather than uniformly distributed in the joint and conductor. This could be an important factor in magnet design, since localized yielding would release energy in the form of heat. This heat could affect refrigeration requirements for the magnet; and if the joint were not in good thermal contact with the liquid helium, degradation of the superconducting properties could occur.

\section{CONCLUSIONS}

On the basis of our work to date on soldering, inspecting, and testing of copper-clad Nb-Ti superconductor composite material, we draw the following conclusions:

1. A large number of commercial solders with a wide range of both commercial and experimental fluxes readily wets and flows on the copper cladding of the superconductor.

2. No combination of solder and flux investigated wets the $\mathrm{Nb}$-Ti filaments.

3. A resistance-soldering technique using graphite electrodes appears to be feasible for fabricating lap joints in a superconductor composite.

4. X-ray radiography reveals relatively thick defects in soldered joints, but not in nonbond areas having essentially metal-to-metal faying-surface contact.

5. Thermal evaluation of the soldered joints with a commercial infrared-sensitive imaging system was not possible. The equipment response time was too slow for the fast transients in the high thermal diffusivity matrix.

6. Through-transmission ultrasonic inspection appears very promising for detecting nonbond areas (as well as pores) in soldered lap joints.

7. A flux of composition $383 \mathrm{~g} \mathrm{ZnCl}_{2}-38 \mathrm{~g} \mathrm{NH}_{4} \mathrm{Cl}-40 \mathrm{ml} \mathrm{HCl}-100 \mathrm{ml} \mathrm{H}_{2} \mathrm{O}$ was selected as the optimum experimental flux for soldering this superconductor, on the basis of its performance in wettability and flow tests and its ease of removal after soldering. 
8. Resistance-soldered joints made with a solder of composition $97.5 \mathrm{~Pb}-1.5 \mathrm{Ag}-1 \mathrm{Sn}$ had the highest single-lap shear strength and elongation at $-269^{\circ} \mathrm{C}(4 \mathrm{~K})$ of four solders tested, while joints of $95 \mathrm{Sn}-5$ $\mathrm{Ag}$ had the lowest strength and elongation at that temperature. This evidence reinfurces the previously reported data on the detrimental effect of high tin content on mechanical properties at cryogenic temperatures.

\section{RECOMMENDATIONS FOR FUTURE WORK}

Before soldered joints can be incorporated in the windings of large magnets for fusion reactors, a number of development studies must be conducted. If the chosen superconductor composite is copper clad, this future work could be a continuation of the preliminary studies begun in this program. However, if some other cladding material (such as aluminum) is used, then an essentially new investigation would have to be initiated, since the soldering characteristics would be significantly different from those of copper.

The next logical task necessary to qualify a given solder or solders for joints in magnets would be electrical-resistivity measurements with the sample under stress and in the presente of strong magnetic fields. These tests would more closely approximate actual magnet conditions and provide designers with data concerning the amount of overlap required in the joints to achieve sutticiently low joint resistance. Included in these tests (and in additional mechanical property tests) should be samples which have been aged isothermally at $4 \mathrm{~K}$ as well as those which have been thermally cycled between cryogenic and room temperatures. Tests of this type are necessary to ensure that the resistivity and strength properties used in coil design are not detrimentally affected by long-term aging.

Another area requiring future work is in the possible corrosion problems caused by incompletely removed or trapped fluxes. Techniques should be developed for flux removal and for determination that a flux has in fact been "completely" removed. Also, the effect over a period of time of residual flux (particularly that trapped within the joint itself) on the composite materials should be studied.

Third, various techniques such as ultrasonic agitation should be investigated as a means to promote wetting of the superconductor filaments. Our preliminary work has shown that copper-clad composite with exposed $\mathrm{Nb}$-Ti filaments apparently was wet by several different solders when tinned with a soldering iron containing a transducer oscillating at high frequencies. However, these specimens dewet at the $\mathrm{Nb}-\mathrm{Ti}$ filaments when reheated, which indicates that the film of solder may have merely bridged over the filaments during ultrasonic tinning. Accordingly, this technique should be carefully studled to see wlietlier it in fact promotes wetting of the superconductor.

Finally, a more complete program should be conducted to further develop cquipment and techniques for nondestructively veritying the quality of the soldered joints.

\section{ACKNOWLEDGMENTS}

The autlius would likr to acknowledge the following individuals who made significant contrihutions to this paper. L. T. Ratcliff of the Mechanical Properties Group conducted the lap-shear tests at room and liquid-nitrogen temperatures. J. W. Nave and J. R. Mayotte of the General Metallography Group were responsible for the photographic work. W. J. Mason, W. A. Simpson, and K. V. Cook of the Nondestructive Testing Group conducted the nondestructive evaluation studies. R. G. Shooster of the Administrative Services Group was responsible for the machining of samples and equipment. The manuscript was reviewed by J. F. King and C. J. Long and edited by L. Foster. The various drafts were typed by Kathy Gardner, and the final manuscript was prepared by Mary Guy. Finally, we would like to express our appreciation to G. M. Slaughter for his technical advice and support in conducting this program. 
1-2. Central Research Library

3. Document Reference Section

4-5. Laboratory Records Department

6. Laboratory Records ORNL RC

7. ORNL Patent Office

8. E. S. Bettis

9. C. R. Brinkman

10. R. L. Brown

11. D. A. Canonico

12. J. F. Clarke

13. J. H. DeVan

14. R. G. Donnelly

15-20. D. S. Easton

21. D. P. Edmonds

22. W. A. Fietz

23. G. M. Goodwin

24. P. N. Haubenreich

25. R. L. Heestand

26-28. M. R. Hill

29. J. F. King

30. R. T. King

31. C. C. Koch

32. K. C. Liu

33. C. J. Long

34. A. L. Lotts

33. M. S. Lubell

36. J. N. Luton

37. J. R. Miller

38. R.W. McClung

39. R. E. McDonald

40. J. W. McEnerney

41. C. J. McHargue

42-56. A. J. Moorhead

57. O. B. Morgan

58. P. Patriarca

59. M. Roberts

60. M.W. Rosenthal

61-62. J. L. Scott

63-72. G. M. Slaughter

73. D. Steiner

74. D. B. Trauger

75. J. R. Weir

76. F.W. Wiffen

77. J. J. Woodhouse 
78-79. ARGONNE NATIONAL LABORATORY, 9700 South Cass Avenue, Argonne, IL 60439

J. R. Purcell

80. AMES LABORATORY, Iowa State University, Ames, Iowa 50010

M. S. Wechsler

81-82. BROOKHAVEN NATIONAL LABORATORY, Upton, NY 11973

A. N. Goland

C. L. Snead, Jr.

83. ATOMiCs INTERnATIONAL, P.O. Box 1608, Canoga Park, CA 91340

H. Farrar

84. BATTELLE, PACIFIC NORTHWEST LABORATORY, P.O. Box 999, Richland, WA 99352

I T. Rrimhall

85. SANDIA LABORATORIES, P.O. Box 5800, Albuquerque, NM 87115

S. T. Picraux

86. SANDIA LABORATORIES, Livermore, CA 94550

W. Bauer

87-88. WESTINGHOUSE ELECTRIC CORPORATION, Research and Development Center, Pittsburgh, PA 15235

R. E. Gold

J. M. Wells

89. THE UNIVERSITY OF WISCONSIN, Nuclear Engineering Department, Engineering Research Building, Room 433, Madison, WI 53706

R. W. Conn

G. L. Klucinski

90-95. ERDA DIVISION OF MAGNETIC FUSION ENERGY, Washington, DC 20545
M. M. Cohen
E.N.C. Dalder
C. K. Fintgeid
T. C. Reuther, Jr.
J. M. Williams
K. M. Zwilsky

96. ERDA DIVISION OF PHYSICAL RESEARCH, Washington, DC 20545

L. C. Ianniello

97-98. ERDA DIVISION OF REACTOR DEVELOPMENT AND DEMONSTRATION, Washington, DC 20545

E. E. lloftman

J. R. Hunter

99-100. ERDA,OAK RIDGE OPERATIONS OFFICE, P.O. Box E, Oak Ridge, TN 37830

Director, Reactor Division

Dircctor, Rescarch and Technical Suppürt Divisiun

101-127. ERDA TECHNICAL INFORMATION CENTER, P.O. Box 62, Oak Ridge, TN 37830 